\title{
GREEN BANKING CONCEPTS IN QUR'AN REVIEW
}

\author{
M. Zainal Arifin ${ }^{1}$, Muhammad Noor Sayuti2 ${ }^{2}$, Tiara Septa Ayu ${ }^{3}$, Ali Sadikin ${ }^{4}$ \\ 1234 Faculty of Islamic Economics and Business IAIN Palangka Raya \\ 1muhammadzainalarifin62@gmail.com \\ 2m.noor.sayuti@iain-palangkaraya.ac.id \\ 3tiarasepta11@gmail.com \\ 4alisadikin030335@gmail.com
}

\begin{abstract}
This study aims to describe the concept of Green Banking in the review of the Qur'an through the approach of ljmali and Maudhu's interpretation method as its analysis knife. Content analysis is carried out on the verses that are specifically chosen on the basis of their association with the term fasad in the category of environmental damage namely Surah AlBaqarah [2]: 205 and Surah Ar-Rum [30]: 41. This is because the beginning of the concept of green banking emerged due to environmental damage ,. The research findings revealed from the two verses that it was found that the meaning of damage meant in essence was natural damage (both physical and non-physical) due to anthropogenic factors. Islamic banking in the provision of financing must prioritize projects that are pro-environment and pay attention to aspects of sustainability, both economic, socio-cultural environment or known as Triple $P$ (People, Planet and Profit) with the principles of fairness, balance, benefit, economical and avoid the tyranny.
\end{abstract}

Keywords: Al-Qur'an, fasad, Green Banking.

\section{A. INTRODUCTION}

Climate change and environmental conditions are increasingly worsening to the attention of each country to determine strategies in response to this, as well as the Indonesian state. According to data from the Ministry of Environment \& Forestry, the National Environmental Quality Index (IKLH) in 2017 (66.46) shows an increase of 0.73 compared to the National IKLH in 2016 (65.73). (Subbidang Penyaji Informasi Kementerian Lingkungan Hidup dan Kehutanan, 2017: 23)

The impact of climate change and the increasingly serious environmental conditions make all parties aware and act to develop strategies to preserve the environment. It is not enough to involve the involvement of government agencies and industrial sectors that are directly related to nature such as mining and so on which are very vulnerable to causing natural damage. On the other hand, development activities can also cause changes, both the natural environment and social environment. It is important that efforts are made so that these environmental changes do not disturb the balance of relations between humans and the environment. 
Therefore, the direction of the policy of implementing state development regulated in TAP / IV I MPR / 1999 concerning the State Policy Outline (GBHN) of 1999-2004 is based on environmental management policies. Namely, in terms of management, utilization and utilization of HR. The regulation is also supported by Law No. 32 of 2009 concerning Environmental Protection and Management (UUPPLH). All sectors of activities related to the environment must consider the sustainability of the environment. Starting from the economic and business side, all private sector and SOE institutional business sectors are not only focused on profitability, but also how to reduce the impact caused by their production activities.

Banking financial institutions as one of the important pillars in supporting the SDG (Sustainable Development Goals) need to be enhanced and expanded in their role, so as to provide optimal benefits, and strategic functions. Economic instruments through banking financial institutions need to adapt interdependently with the environment, acting as agents of development in realizing SDG through environmental protection and management efforts. This strategy is known as the green banking concept

The mission is in line with the program initiated by UNEP (United Nations Environment Program) that development must be based on a green economy. Namely, the process of reconfiguring business and infrastructure to deliver better results to nature and people, investment in economic capital, greenhouse emissions, extraction and use of less natural resources with minimal waste and minimum social inequalities.(Aisyah, 2016: 55)

As one of the suppliers of funds, both conventional and sharia-based bank financial institutions are now not only focused on profit, but also consider the relevance of their activities to environmental impacts. It is only natural for financial institutions or institutions that channel funds to stakeholders to consider environmental sustainability.(Maramis, 2013: 108)

It should be that the discourse of the threat of global environmental crisis becomes an actual issue that must be given attention by Islamic banking, especially its role in reducing anthropogenic impacts, because basically the Al-Qur'an and As-Sunnah which form the foundation of Islamic financial institutions explicitly prohibit behavior destructive way described in terms of fasad.

This paper will discuss the issue of environmental crisis caused by anthropogenic factors or hazards caused by human activities from the perspective of the Qur'an, and its relevance to the concept of Green Banking or environmentally friendly banking.

\section{B. METHOD}

The paradigm used in this study is qualitative research based on the philosophy of postpositivism which is usually used to examine natural objective conditions in which researchers act as key instruments, while the type is library research (Library Research). This research will be examined through the ljmali and maudhu'l interpretation method approach as the analysis knife, by describing the term fasad interpretation in ijmali (global), which explains 
the verses of the Qur'an briefly and globally, without elaboration, with a popular language style that is easy to understand from the classical commentaries namely Ibn Kathir and Tafsir Jalalain's interpretation and supported by modern interpretations such as Al-Misbah's interpretation as primary data, then analyzed using the maudhu'l (thematic) method specifically relating to the theme of damage environment, namely the QS Al-Baqarah [2]: 205 and QS ArRum [30]: 41. Furthermore, it is also reviewed based on the views of the fiqh scholars and the MUI DSN fatwas in this case as secondary data. It is intended that researchers can draw a red thread from the interpretation of these two verses, so that researchers can examine their relevance to the concept of green banking and its application in Islamic banking.

In this study, the data analysis technique used is content analysis, which is to analyze the meaning contained in the data collected through a literature review, or as a technique used to draw conclusions through an effort to find the characteristics of the message and be carried out objectively and systematically.

\section{RESULTS AND DISCUSSIONS}

\section{Green Banking Concept}

Green Banking is a new paradigm in the international banking industry that is developing over the past decade. The concept was born as a response to the demands of the global community who asked the banking industry to actively participate in efforts to overcome the environmental crisis and global warming which is increasingly serious. The concept of green banking is an effort to strengthen the ability of bank risk management, especially related to the environment and encourage banks to increase environmentally friendly financing portfolios (Yuniarti, 2013: 464). Specifically, green banking means that banks no longer only focus on financial responsibilities, namely managing their business as well as possible to generate maximum profits for shareholders. (Zhelyazkova \& Kitanov, 2015: 313) The focus of his responsibility is on efforts to preserve the environment and the universe and improve social welfare for the community. merging these three aspects into a report called the sustainability report. Sustainability reports are also known as Triple Bottom Line (TBL) or Triple P reports (People, Planet dan Profit).(Arowoshegbe et al., 2018: 104) The concept of TBL implies that banks must prioritize the interests of stakeholders (all parties involved and affected by the activities carried out by the company) rather than the interests of shareholders (shareholders). Green banking has begun to be echoed by Bank Indonesia and the Ministry of Environment in the MoU on December 17, 2010 in the theme of "green banking", which is a concept of financing and other banking service products that prioritize aspects of sustainability, both economic, socio-cultural environment, and technology simultaneously.

Green Banking is a general term that refers to the practices and guidelines of banks in sustainable development. Use the Environmental Impact Analysis (AMDAL) on the concept of "Green Banking" to drive the banking economy so as to help reduce environmental pollution. Banks in the process of financing a development must see the impact on environmental sustainability.(Bhardwaj, 2013: 181) 
The concept of green banking is very closely related to the term green financing. Green financing can be interpreted as a loan facility from financial institutions to debtors engaged in the business sector that does not have an impact on environmental quality or social conditions. In banking financing, risk analysis is not only limited to analysis based on project performance, but also requires a method of analysis that takes into account external costs (benefit and risk analysis) involving various disciplines (inter and multidiscipline science), specifically to understand the environment. With the enactment of the Banking Act and as a result of the implementation of prudent banking principles and the problem of the soundness of banks, the banking sector will certainly be very concerned about environmental issues.

In terms of financing, Islamic banking can participate in environmental management, because companies that want to develop depend on credit facilities. As one of the financial backers, banks not only see economic considerations but also environmental integration. In Article 22 paragraph (2) of Law No. 32 of 2009 concerning Environmental Protection and Management (UUPPLH), to determine an activity that has a significant impact on the environment is determined by :

a. The number of people who will be affected;

b. Area of impact distribution;

c. The intensity and duration of the impact;

d. The number of other environmental components affected;

e. The cumulative nature of the impact;

f. Reversible or irreversible impacts;

g. Other criteria are in accordance with the development of science and technology.

The whole thing needs to be studied because the banking sector that functions as an intermediary in development has mobilized and distributed funds to the community, among others in the form of financing to industries in the development process. This means that there must be follow-up and cooperation with other parties who are given the task to oversee environmental problems. According to (Nasution, 2018: 38) in directing environmentally sound financing policies, examples of provisions that must be submitted to prospective debtors in the process of granting and approving their financing are:

1. AMDAL as a licensing requirement for every activity that has a significant impact on the environment;

2. Decision on approval of the Environmental Management Plan (RKL) and Environmental Monitoring Plan (RPL) in accordance with the requirements;

3. Environmental statement from the company / prospective debtor;

4. Internal monitoring, i.e. monitoring activities carried out by the company / debtor carefully the state of the facility, operations and influence on the environment and report it periodically, both to the government and banks; and

5. Inspection / trade checking, namely monitoring activities carried out by Islamic banks to see the extent of compliance and operation as well as the influence on the environment. By the finance committee this was reported as a report on the results of debtor visits.

Radyati (2014: 12) explain the concept of green banking has the following scope: 
1. Internal: implementing efficiency programs and R3 (Reduce, Reused, Recycle), among others, by optimizing the power of innovation and creativity of employees and by utilizing technological tools.

2. External: educate stakeholders through environmentally friendly programs and offer eco-products to customers.

a. Corporate Social Responsibility (CSR): carry out activities in order to improve the quality of the environment and community empowerment or engage in green business socialization.

b. Credit: lending to environmentally friendly sectors or industries such as renewable energy, organic products, creative industries that utilize waste, high-end products, waste processing, and agriculture and forestry, providing interest incentives to debtors who have businesses an environmentally friendly model, applying the principle of sustainability in the analysis of debtor's credit worthiness gradually as part of the credit clause and is believed to be the two-step loan distributor of global institutions for environmental projects.

c. Funds: provide current, savings or time deposit products affiliated with environmental community accounts.

\section{Green Banking in Review of the Qur'an}

With regard to the Qur'anic review, the holistic-integralistic picture of Islam about the environment can be traced from the Qur'anic doctrine through term facas in the category of environmental damage. This is because the beginning of the concept of green banking can emerge is due to environmental damage that is now increasingly prevalent. The participation of banking institutions in realizing this go green turned out to have a strong foundation of the meaning of the Qur'an.

The Qur'an has a variety of terms. Among the terms in the Qur'an that relate directly to environmental damage is the term fasad, which is repeated 50 times in the Qur'an. The meaning of brevity is something out of balance. The scope of the meaning of facas turns out to be quite broad, namely concerning the soul / spirit, body / physical, and anything that deviates from the balance / which should be.

Term facas in the Qur'an can be classified with several meanings, First, interpreted by acts of shirk and immorality. This can be proven in Q.S Al-A'raf [7]: 56 (Al-Mahali \& Al-Suyuti, 2003: 408) in this verse is interpreted by the deeds of shirk (الثرك)) and immoral acts (المعاص). Secondly, it can be interpreted also irregularity or out of order (خرجتاعن نظامها) as in Q.S AlAnbiya [21]: 22 (Al-Mahali \& Al-Suyuti, 2003: 323) Third, it can mean destructive or tearing down (تخريب) as in Q.S An-Naml [27]: 34 (Al-Mahali \& Al-Suyuti, 2003: 379) Fourth, meaning the environmental damage described in QS Al-Baqarah [2]: 205 and QS Ar-Rum [30]: 41 Namely a hypocritical human nature (turned away from Him) to do damage on earth to plants and animals livestock in a way on purpose. 
Paying attention to the interpretation above the term facas in the Qur'an can be divided into several categories, namely:

a. Deviant and unwholesome behavior;

b. Irregularity / mess;

c. Destructive behavior (damaging);

d. Environmental damage.

This research will discuss terms in the category of environmental damage. As for the verses of the Qur'an that deal more specifically with environmental damage, there are QS AlBaqarah [2]: 205 and Q.S Ar-Rum [30]: 41.

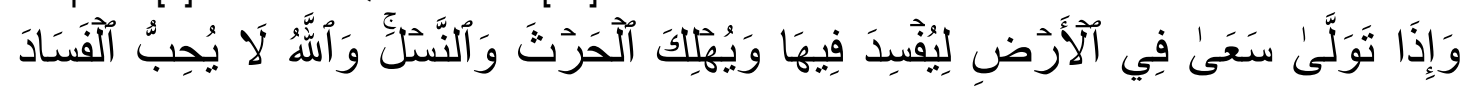

Meaning: And if he turns away (from you), he walks on earth to do damage to him, and destroy crops and animals, and Allah does not love destruction

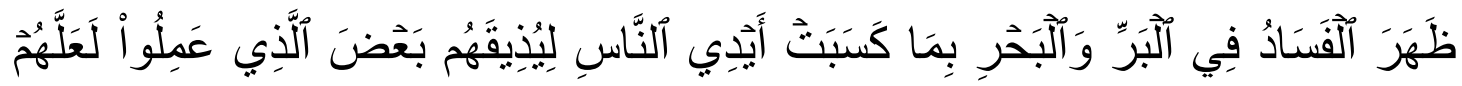

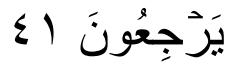

Meaning: It has been seen that damage on land and at sea is caused by the deeds of human hands, so that Allah feels to them part of their actions, so that they return (to the right path)

Globally the interpretation of the first verse is interpreted by deviant speech and evil acts of hypocrites. le, his words were lies and his beliefs were broken, his actions were all bad. The hypocrites mentioned in this verse are those whose actions only cause damage to the earth and destroy crops, including in this sense rice fields and fruits, as well as livestock, both of which are staple foods for humans.(Katsir, 2000: 164) In a broader view, where is the sentence al-ḥarts wa an-nasl is not only translated with plants and livestock, it can also be understood in the sense of women and children, that is, they carry out activities that harass women and damage the younger generation, and the word (تََّلْىى) tawalla is understood in the sense of ruling, then this type of human being is very articulate, offers amazing programs, so that he is finally elected as a ruler, but when in power, he harasses women and young people, and does a variety of destruction.(Shihab, 2002a: 446)

Observing the above interpretation of the treatment of powerful people who are very losers. If we narrow the scope of the discussion, then this is divided into several points of view. The first is about environmental damage to living things in the form of plants and livestock. We can prove this by the increasingly widespread environmental damage caused by human activity, especially in the business and industrial sectors that have a direct impact on nature such as oil palm plantations, coal, industries that are not responsible for the waste they produce, and there are many other examples. 
Second, namely the destruction of humans, both physically and non-physically mentioned are women and children or young people who are very vulnerable affected by negative things. This context leads more to moral or human character, which in fact is getting worse lately.

The third point of view is the damage that occurs in the two previous points of view will also affect the next generation / heredity (hifdz an-nasb). This is related to each other, when humans no longer have morals and morals (both to fellow human beings, and the surrounding environment) then God will lower the punishment for human actions themselves. This will greatly affect the lives of the next generation.

The second paragraph explicitly describes the anthropogenic damage. Namely the prolonged dry season is a result of the interruption of rain that does not water the earth, then arises a period of famine, reduced crops and livestock animals whose causes are none other than because of immoral acts committed by humans to deliberately achieve a certain goal. Thus in this verse Allah classifies these people into the group of polytheists.(Katsir, 2000: 1028)

The above verse mentions the land and sea where the fasad happened. This can mean that land and sea become an arena of damage, and it can also mean that land and sea itself have experienced damage, imbalance and lack of benefits. The sea has been polluted, so fish die and sea products are reduced. The land is getting hotter so that there is a long dry season. As a result, the environmental balance becomes chaotic.(Shihab, 2002b: 77)

This is what led us while contemporary scholars understood this verse as a sign of environmental damage. That the above verse does not mention the air, it may be because what is emphasized here is what appears only, as the meaning of the word zahara that has been alluded to above, especially when the passage of this verse, human knowledge has not reached the sky, especially about pollution. But that does not mean this verse limits only the surface of the earth and sea.

We should pay close attention to this verse. Allah has sent humans to this earth is to become the Khalifah of Allah, which means executing God's will. Many secrets of the Greatness and Divine Power become clear in the world, because of human effort. Therefore, then become a Khalifah should be Mushlih, meaning like to improve and beautify.(Hamka, n.d.: 73)

Related to the above verse Allah reminds people through Q.S Al-A'raf [7]: 85 about the advice of the Prophet syu'aib to his people (adyan) who like to do mischief or damage on earth, deceiving by damaging bushels (scales). When the message of God in this verse is contrasted with the previous verse it is clear that when the hearts of men have been corrupted, because their intentions have been evil, damage will surely occur on earth. The human heart imprints on its actions.(Hamka, n.d.: 74)

Relevant to the concept of green banking, the two verses above describe the damage that leads to nature. The key word is on the interpretation of the word fasād which means damage to nature (both physical and non-physical) caused by the behavior of exploiting nature on a 
large scale that is uncontrolled and ignores the environment, so that it can cause damage or deterioration in the quality of the environment, which in turn can threaten the sustainability and availability of natural resources, where the quality of the environment can affect the quality of society.

Paying attention to the verses which become theological doctrine on this environment, then it is recognized or not, the law of its maintenance is mandatory and damaging it is haram. If this doctrine is associated with Islamic legal methods, namely the Five Basic Rules (al-Dharuriyah al-Khamsah) which form the basis of shari'ah objectives (maqashid asy-shari'ah), namely preserving religion, soul, reason, wealth and progeny. Maintenance of the five main problems is directly related to the maintenance of the environment. In simple terms, environmental preservation becomes a pre-requisite in realizing the objectives of the Shari'ah as the principles of jurisprudence say "maa la yatimmu al-wajib illa bihi fahua al-wajib".(Al-Borneo \& Al-Ghazi, 2003: 33) (Mandatory matters that are imperfect except with it, the intermediary becomes mandatory). Cases of anthropogenic environmental damage such as forest and land fires (karhutla) can cause multidimensional losses including social, environmental, political and even economic impacts. Minimizing the impact of damage (mafsadat) is the goal of the Shari'a.

An economic study of the effects of forest and land fires in 1997/1998 by Tacconi (2003) showed that these fires resulted in economic degradation and deforestation valued at 1.62-2.67 billion dollars, costs due to haze totaling 674-799 million dollars and valuation of carbon emissions of 2.8 billion dollars. Social impacts that are directly felt by the community are health, such as asthma, bronchitis, ARI, to death, and the impact of job loss.(Amri et al., 2016: 96) Therefore All that lead to the maintenance of the Five goals is a suggestion and even an obligation. On the contrary, everything that hinders and ignores these objectives is prohibited with various levels of prohibition. Maintenance of the soul is directly related to environmental care, all forms of destruction that cause landslides, erosion, flooding can damage the existence of the human soul. Exploitation of nature is one form of destruction of property as the main goal of the fifth religion because nature is a gift of God provided for the needs and survival of humans. Water, forests, earth's minerals and all natural wealth are infinite treasures and are provided for the needs of His creatures.

Islamic Sharia is very concerned about protecting the environment, as the following hadith of the Prophet: (Al-Sijistani, 2009: 530)

$$
\text { من قطع سدرة (شجرة سدر وهو النبق ) صوّب الله رأسه في النار }
$$

Meaning: Anyone who cuts down a lion tree will surely have Allah's head plunged into hell. (H.R. Ahmad)

Commenting on Ahmad's hadith above, Yusuf al-Qardhawi (2010: 78) explains the urgency of forests in balancing climate and invites humans to reduce the negative impacts of industrialist life that can harm the environment. Researcher's point of view, he implicitly shows his concern for environmental damage. That is, he indirectly also gave his support for the concept of green banking which aims to preserve the environment.

Decision of the International Jurisprudence Association on Environment (Al-majma 'Al-Figh AlIslami Al-Dauli) in its 19th workshop has released decision number 185 (11/19) Regarding the environment and its safeguards in Islamic review, one of them is:(Al-Qardhawi, 2010: 81) 


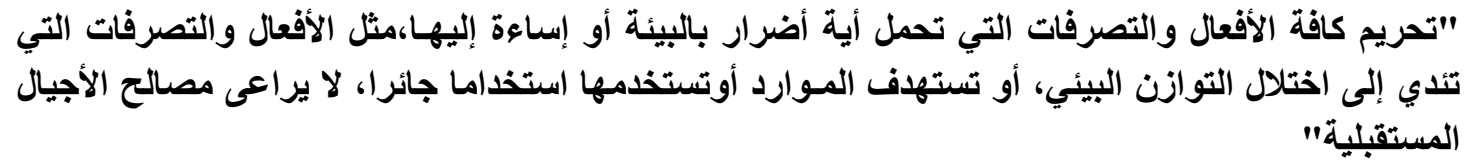

Meaning: All activities and ill-treatment are forbidden that can damage or harm the environment, which can damage the balance, or exploit its resources, or misuse without regard to the interests of future generations.

Based on the fatwa, the prominent ulemas who are members of the International Jurisprudence Association have agreed that preserving nature is very important. Islam as a religion rahmatan lil 'alamin really cares about its regeneration from any aspect. One aspect is environmental issues. When the current generation does not heed or even misuse and exploit natural resources excessively without any repairs, it will certainly cause various kinds of damage and natural disasters that will occur for the next generation. Thus, the concept of maslahah in the maqasid asy-shariah regarding safeguarding of religion, soul, reason, wealth, and offspring will not be achieved perfectly.

According to Yusuf al-Qardhawi, protecting the environment is the same as protecting religion, protecting the soul, protecting the mind, protecting the offspring, and protecting the wealth. The rationale is that if aspects of religion, soul, reason, descent, and property are damaged, then human existence in the environment will be tarnished. The concept of environmental fiqh (figh al-bi'ah) formulated by Muslim scholars reflects the dynamics of figh associated with changing contexts and situations (Al-Qardhawi, 2001: 46). Facing environmental issues, the Indonesian Ulema Council also contributed to this by issuing a fatwa on environmental sustainability. As for some examples of fatwa namely:

a. DSN-MUI Fatwa Number 22 Year 2011 Concerning Environmentally Friendly Mining;

b. DSN-MUI Fatwa Number 30 Year 2016 Concerning Law on Forest and Land Burning and Its Control;

c. DSN-MUI Fatwa Number 47 Year 2014 Regarding Waste Management to Prevent Environmental Damage.

In realizing that, a global commitment is needed. Islamic banking has the main function as a collector and distributor of public funds. However, the Islamic banking sector in its participation in providing development financing must still consider the principle of prudence. The aim is to support the implementation of national development in order to improve equity, economic growth and national stability towards improving people's welfare. Project financing that has an environmental perspective has been proven to increase competitiveness and provide its own advantages for banks that implement it as a business strategy.

Islamic banks should be in the forefront in implementing the current green banking policy. A number of Islamic banks are already active in providing financing for new and renewable energy development businesses, financing for increasing industrial energy efficiency, and financing environmentally friendly integrated agriculture. Green banking in sharia banks is based on project financing strategies or environmentally friendly and socially friendly businesses which target is the maintenance of environmental sustainability and social stability 
of the community (Radyati, 2014: 41). Financial Services Authority Regulation Number 31 / POJK.05 / 2014 governing Sharia Business Financing, i.e.:

\section{Adl (عادل)}

Put things only in their place, and give something only to those who are entitled to and treat things according to their position. In its support of the green banking regulation, which provides companies with limits to managing their waste or sharia banking does not support the production of companies that do not care about waste management, thus causing injustice to the local communities affected by the waste from the company. This is in accordance with the contents of the purpose of environmental preservation in Law No. 32 of 2009 in part: (a.) Protecting the territory of the Unitary State of the Republic of Indonesia from environmental pollution and / or damage; (b.) guaranteeing safety, health and human life; (c.) guarantee the survival of living things and the preservation of ecosystems; and (d.) controlling the wise use of natural resources;

\section{Tawaẓun (توظن)}

The balance of material and spiritual aspects, the private and public aspects, the financial sector and the real sector, business and social, and the balance of aspects of utilization and sustainability. In its support of green banking regulations, the company is limited in producing so as not to exploit. This is in accordance with the contents of the purpose of environmental preservation in Law No. 32 of 2009 in part: achieving harmony, harmony, and environmental balance;

\section{Mașhlahah (المصلحة)}

All forms of goodness with worldly and ukhrawi dimensions, material and spiritual as well as individual and collective and must meet 3 elements, namely:
a. Sharia (halal) compliance
b. Useful and
c. Bring goodness (tayyib).

With this sharia principle, providing support for not financing companies that produce goods that are not halal, bring bad and useless. This is in accordance with the contents of the purpose of environmental preservation in Law No. 32 of 2009 in part: realizing sustainable development; and anticipating global environmental issues.

\section{Almiyah (الميه)}

Something that can be done and accepted by, with, and for all interested parties (stakeholders), regardless of ethnicity, religion, race, and class, in accordance with the spirit of universal respect (rahmatan lil alamin). This principle becomes the role to not apply anything and anyone arbitrarily, including the environment, flora, and fauna. This is in accordance with the contents of the purpose of environmental preservation in Law No. 32 of 2009 in part: maintaining the preservation of environmental functions.

\section{Zāalim (الظالمين)}

Something that can be done and accepted by, with, and for all interested parties (stakeholders), regardless of ethnicity, religion, race, and class, in accordance with the spirit of universal respect (rahmatan lil alamin). This principle becomes the role to not 
apply anything and anyone arbitrarily, including the environment, flora, and fauna. This is in accordance with the contents of the purpose of environmental preservation in Law No. 32 of 2009 in part: maintaining the preservation of environmental functions.

From the explanation above, it can be seen that the principles of sharia are relevant and do not conflict with the objectives of green banking regulation, even far from before the discourse of green banking sharia principles actually have taken a big role in environmental preservation or preservation. Of course, the concept of green banking is welcomed by Islamic banking because it is in accordance with its principles.

\section{CONCLUSION}

The concept of green banking, if viewed from the perspective of the Qur'an, can be found in a holistic-integralistic picture of meaning implicitly, that is, in terms of facade or which means damage. From the two verses of QS Al-Baqarah [2]: 205 and QS Ar-Rum [30]: 41 it is found that the meaning of damage meant physically is physical damage, as well as the meaning of majazi namely non-physical damage which is anthropogenic, the damage caused by the behavior of hypocrites or human mental crises which in turn have an impact on the damage to the intrinsic meaning that is damage to nature, both on land and at sea.

The relevance of the concept of green banking with the meaning of the two paragraphs above is that the concept of Green banking as a benchmark to see risk factors in the provision of financing that prioritizes projects or businesses that are pro to the environment, with the principles of fairness, balance, benefit, economical and avoid the injustice that is implemented through financing and other banking service products that prioritize sustainability aspects, both economic, socio-cultural environment or known as Triple P (People, Planet and Profit). The contract scheme used in the green banking model is like a contract at a commercial bank. The difference is that the green banking model is given to companies / projects that are guaranteed to be environmentally friendly / not damage the environment. 


\section{REFERENCES}

Aisyah, D. A. N. (2016). Aspek Hukum Penerapan Green Banking Dalam Kegiatan Kredit di PT. BNI (Persero) Tbk. Jurnal Privat Law, IV.

Al-Borneo, M. S. I. A. I. M., \& Al-Ghazi, A. A.-H. (2003). Mausu'ah al-Qawaid al-Fiqhiyyah. Beirut: Resalah.

Al-Mahali, J., \& Al-Suyuti, A. J. (2003). Tafsir al Jalalain. Beirut: Dar al-Khair.

Al-Qardhawi, Y. (2001). Islam Agama Ramah Lingkungan. (A. H. Shah, Trans.). Jakarta: Pustaka Al-Kautsar.

Al-Qardhawi, Y. (2010). al-Qawaid al-Hakimah li Fiqh al-Mu'amat. Beirut: Dar al-Syuruq.

Al-Sijistani, A. D. (2009). Sunan Abi Dawud (Vol. 4). Beirut: Dar al-Kutub al-'Arabi.

Amri, M. R., Yulianti, G., \& Yunus, R. (2016). Risiko Bencana Indonesia. Jakarta.

Arowoshegbe, A., Emmanuel, U., \& Gina, A. (2018). Sustainability And Triple Bottom Line: An Overview Of Two Interrelated Concepts.

Bhardwaj, B. R. (2013). Green Banking Strategis: Sustainability Through Corporote Entrepreneurship. Jakarta: University Press.

Hamka. (n.d.). Tafsir al-Azhar (Vol. 7). Singapura: Pustaka Nasional PTE LTD.

Katsir, I. (2000). Tafsir Ibnu Katsir. Beirut: Muasasah al-Risalah.

Maramis, N. F. (2013). Tanggung Jawab Perbankan Dalam Penegakan Green Banking Mengenai Kebijakan Kredit. Jurnal Hukum UNSRAT, XXI.

Nasution, R. (2018). Sinergi dan Optimalisasi Green Banking Dalam Mewujudkan Sustainable Finance. Jurnal IImu Ekonomi dan Studi Pembangunan, 18.

Radyati, A. (2014). Urgensi Pengaturan Green Banking dalam Kredit Perbankan di Indonesia. Unversitas Brawijaya. Diambil dari http://repository.ub.ac.id/id/eprint/156610

Shihab, M. Q. (2002a). Tafsir Al-Misbah (Pesan, Kesan, dan Keserasian Al-Qur'an) (Vol. I). Jakarta: Lentera Hati.

Shihab, M. Q. (2002b). Tafsir Al-Misbah (Pesan, Kesan, dan Keserasian Al-Qur'an) (Vol. 11). Jakarta: Lentera Hati.

Subbidang Penyaji Informasi Kementerian Lingkungan Hidup dan Kehutanan. (2017). Indeks Kualitas Lingkungan Hidup 2017. Jakarta.

Yuniarti, S. (2013). Peran Perbankan Dalam Implementasi Bisnis hijau dan Pembangunan Berkelanjutan. Jurnal Keuangan dan Perbankan, 17.

Zhelyazkova, V., \& Kitanov, Y. (2015). Green Banking-Definition, Scope And Proposed Business Model. 